\title{
Stoichiometry of $\mathrm{Na}^{+}-\mathrm{HCO}_{3}^{-}$Cotransport in Basolateral Membrane Vesicles Isolated from Rabbit Renal Cortex
}

\author{
Manoocher Soleimani, Steven M. Grassl, and Peter S. Aronson \\ Departments of Medicine and Physiology, Yale University School of Medicine, New Haven, Connecticut 06510
}

\begin{abstract}
The major pathway for $\mathrm{HCO}_{3}^{-}$transport across the basolateral membrane of the proximal tubule cell is electrogenic $\mathrm{Na}^{+}-\mathrm{HCO}_{3}^{-}$cotransport. In this study, we have determined the stoichiometry of the $\mathrm{Na}^{+}-\mathrm{HCO}_{3}^{-}$cotransport system in basolateral membrane vesicles that were isolated from rabbit renal cortex by Percoll gradient centrifugation. When the membrane potential is approximated by the Nernst potential for $\mathbf{K}^{+}$, as in the presence of the $\mathrm{K}^{+}$ionophore valinomycin, equilibrium thermodynamics predicts that the $\mathrm{Na}^{+}-\mathrm{HCO}_{3}^{-}$cotransport system should come to equilibrium and mediate no net flux when $(\mathrm{Na})_{1} /$ $(\mathrm{Na})_{0}=\left[\left(\mathrm{HCO}_{3}\right)_{0} /\left(\mathrm{HCO}_{3}\right)_{1}\right]^{n}\left[(\mathrm{~K})_{0} /(\mathrm{K})_{1}\right]^{n-1}$, where $n$ is the $\mathrm{HCO}_{3}^{-}: \mathrm{Na}^{+}$stoichiometry. Our experimental approach was to impose transmembrane $\mathrm{Na}^{+}, \mathrm{HCO}_{3}^{-}$, and $\mathrm{K}^{+}$gradients of varying magnitude and direction, and then to measure the net flux of $\mathrm{Na}^{+}$over the subsequent 3-s period. In this way, we could determine the conditions for equilibrium of the transport system and thereby calculate $n$. The results of these experiments indicate that the value of $n$ is $>2.6$ and $<3.5$, consistent with a stoichiometry of $3 \mathrm{HCO}_{3}^{-}: 1 \mathrm{Na}^{+}$, or a thermodynamically equivalent process. Based on reported intracellular potentials and ion activities, this value for the stoichiometry indicates that the insidenegative membrane potential is sufficient to drive $\mathrm{HCO}_{3}^{-}$exit against the inward concentration gradients of $\mathrm{HCO}_{3}^{-}$and $\mathrm{Na}^{+}$ that are present across the basolateral membrane of the intact proximal tubule cell under physiologic conditions.
\end{abstract}

\section{Introduction}

$\sim 90 \%$ of the filtered load of $\mathrm{HCO}_{3}^{-}$is reabsorbed in the proximal tubule of the kidney by a process of active acid secretion. The principal pathway for uphill movement of acid from cell to tubular fluid is via the luminal membrane $\mathrm{Na}^{+}-\mathrm{H}^{+}$exchanger (1). The pathway(s) for exit of $\mathrm{HCO}_{3}^{-}$across the basolateral membrane of the proximal tubule cell have been less well characterized. Boron and Boulpaep described a process of $\mathrm{Na}^{+}-\mathrm{HCO}_{3}^{-}$ cotransport across the basolateral membrane of the amphibian

A preliminary report of this work was previously published as an abstract (1986. Clin. Res. 34:609A).

Address correspondence and reprint requests to Peter S. Aronson, M.D., Department of Physiology, Yale University School of Medicine, 333 Cedar Street, New Haven, CT 06510.

Received for publication 6 October 1986.

J. Clin. Invest.

(c) The American Society for Clinical Investigation, Inc.

$0021-9738 / 87 / 04 / 1276 / 05 \quad \$ 1.00$

Volume 79, April 1987, 1276-1280 proximal tubule (2). Recent studies suggest that this transport process is also the major mechanism for exit of $\mathrm{HCO}_{3}^{-}$across the basolateral membrane of the mammalian proximal tubule cell (3-10). In addition, $\mathrm{Na}^{+}-\mathrm{HCO}_{3}^{-}$cotransport has been observed in corneal endothelial cells $(11,12)$, suggesting that this pathway is involved in mediating $\mathrm{HCO}_{3}^{-}$transport in epithelial tissues other than the kidney.

In all cases studied to date, $\mathrm{Na}^{+}-\mathrm{HCO}_{3}^{-}$cotransport has been found to be electrogenic and associated with a net flux of negative charge $(2,3,5-8,11)$. This property indicates that the stoichiometry of the cotransport process must involve more than 1 $\mathrm{HCO}_{3}^{-}: \mathrm{Na}^{+}$. Knowledge of the precise stoichiometry is important for predicting the direction of net transport under physiologic conditions. The greater the $\mathrm{HCO}_{3}^{-}: \mathrm{Na}^{+}$stoichiometry, and hence the greater the net negative charge movement per transport event, the more effectively the inside-negative membrane potential of the cell can act as a driving force to bring about the net exit of $\mathrm{HCO}_{3}^{-}$against the $\mathrm{Na}^{+}$gradient normally directed inward across the plasma membrane. For example, recent measurements (13) indicate that the membrane potential would not be sufficient to drive net $\mathrm{HCO}_{3}^{-}$efflux across the basolateral membrane of the rat proximal tubule cell under physiologic conditions if the stoichiometry of cotransport were only $2 \mathrm{HCO}_{3}^{-}: \mathrm{Na}^{+}$or $1 \mathrm{CO}_{3}^{-2}$ : $\mathrm{Na}^{+}$, as has been generally assumed $(2,10,11)$.

Recently, Yoshitomi et al. (5) estimated the stoichiometry of $\mathrm{Na}^{+}-\mathrm{HCO}_{3}^{-}$cotransport across the basolateral membrane of the intact rat proximal tubule cell. These investigators calculated a value of 3, based on comparison of the fall in both intracellular $\mathrm{Na}^{+}$activity and intracellular $\mathrm{pH}$ that occur in response to sudden reduction of peritubular $\mathrm{HCO}_{3}^{-}$concentration. However, the reliability of this value is uncertain because other basolateral membrane transport systems involved in basolateral membrane $\mathrm{Na}^{+}$transport, such as the $\mathrm{Na}, \mathrm{K}-\mathrm{ATPase}$, are known to be markedly pH-dependent (14). Moreover, calculation of the $\mathrm{HCO}_{3}^{-}$flux corresponding to a measured change in intracellular $\mathrm{pH}$ depends critically on estimation of intracellular buffering capacity, which is difficult to determine precisely. Indeed, the same investigators have reported a two-fold range of values for the intracellular buffering capacity in rat proximal tubule cells $(13,15)$.

Accordingly, we have attempted to determine the stoichiometry of the $\mathrm{Na}^{+}-\mathrm{HCO}_{3}^{-}$cotransport system by a method not subject to these uncertainties. We have used a thermodynamic approach to study this problem in basolateral membrane vesicles isolated from the rabbit renal cortex. We previously demonstrated that electrogenic $\mathrm{Na}^{+}-\mathrm{HCO}_{3}^{-}$cotransport is a major pathway for transport of $\mathrm{Na}^{+}$and $\mathrm{HCO}_{3}^{-}$in these membrane vesicles (16). We find that the stoichiometry of $\mathrm{Na}^{+}-\mathrm{HCO}_{3}^{-}$cotransport is $3 \mathrm{HCO}_{3}^{-}: \mathrm{Na}^{+}$or a thermodynamically equivalent process. 


\section{Methods}

Basolateral membrane vesicles were isolated from rabbit renal cortex by differential and Percoll gradient centrifugation, as recently described (16). The membrane vesicles were suspended in a medium consisting of 250 $\mathrm{mM}$ sucrose, $10 \mathrm{mM}$ Hepes titrated to $\mathrm{pH} 7.6$ with tetramethylammonium (TMA) hydroxide, and then frozen and stored at $-70^{\circ} \mathrm{C}$ until used.

Intravesicular content of ${ }^{22} \mathrm{Na}(0.16-0.25 \mathrm{mg}$ membrane protein per sample) was assayed in triplicate by rapid filtration, as previously described (16). The ice-cold medium used to dilute and wash the vesicles consisted of $170 \mathrm{mM} \mathrm{K}$ gluconate, $10 \mathrm{mM}$ Hepes titrated to $\mathrm{pH} 7.5$ with TMA hydroxide. In general, net fluxes of ${ }^{22} \mathrm{Na}$ were assayed over a 3-s interval. $\mathrm{Na}^{+}$uptake with time in the presence of an imposed $\mathrm{HCO}_{3}^{-}$gradient is linear with time for over $3 \mathrm{~s}$ in rabbit renal basolateral membrane vesicles (16), indicating that dissipation of imposed ion gradients is minimal within this time interval. Other details of the experimental protocols are described in the figure legends.

We purchased ${ }^{22} \mathrm{Na}$ from Amersham Corp., Arlington Heights, IL, valinomycin from Sigma Chemical Co., St. Louis, MO, and Percoll from Pharmacia Inc., Piscataway, NJ. Valinomycin was added to the membrane suspension in a 1:100 dilution from a stock solution in 95\% ethanol.

\section{Results and Discussion}

The stoichiometry of a coupled transport process can be determined by finding the electrochemical potential difference of one solute that just balances the electrochemical potential difference of a second solute, thereby bringing the transport process to equilibrium (17). This approach has previously been used to determine the stoichiometry of $\mathrm{Na}^{+}-\mathrm{H}^{+}$exchange (18) and $\mathrm{Na}^{+}-$ glucose cotransport (19) in luminal membrane vesicles isolated from the rabbit renal cortex. For the case of $\mathrm{Na}^{+}-\mathrm{HCO}_{3}^{-}$cotransport, the transport system will be at equilibrium and mediate no net flux when:

$\Delta \tilde{\mu}_{\mathrm{Na}}{ }^{\mathrm{i}-\mathrm{o}}=n \Delta \tilde{\mu}_{\mathrm{HCO}_{3}}{ }^{-\mathrm{i}}$

where $\Delta \tilde{\mu}_{\mathrm{Na}}{ }^{i-o}$ is the in-to-out electrochemical potential difference for $\mathrm{Na}^{+}, \Delta \tilde{\mu}_{\mathrm{HCO}_{3}}{ }^{\mathrm{oi}}$ is the out-to-in electrochemical potential difference for $\mathrm{HCO}_{3}^{-}$, and $n$ is the number of $\mathrm{HCO}_{3}^{-}$cotransported per $\mathrm{Na}^{+}(17)$. Expressing the electrochemical potential differences in terms of the relevant inside and outside ion concentrations and the membrane potential, $V_{m}$, yields:

$$
\begin{aligned}
& {\left[(\mathrm{Na})_{i} /(\mathrm{Na})_{\mathrm{o}}\right] \exp \left(\mathrm{FV}_{\mathrm{m}} / \mathrm{RT}\right)} \\
& =\left\{\left[\left(\mathrm{HCO}_{3}\right)_{\mathrm{o}} /\left(\mathrm{HCO}_{3}\right)_{\mathrm{i}}\right] \exp \left(\mathrm{FV}_{\mathrm{m}} / \mathrm{RT}\right)\right\}^{n} .
\end{aligned}
$$

In the presence of the $\mathrm{K}^{+}$ionophore valinomycin, the membrane potential $V_{m}$ will approach the Nernst potential for $\mathrm{K}^{+}$:

$\mathrm{V}_{\mathrm{m}}=(\mathrm{RT} / \mathrm{F}) \ln \left[(\mathrm{K})_{\mathrm{o}} /(\mathrm{K})_{\mathrm{i}}\right]$.

Combining and rearranging Eq. 2 and 3 gives:

$$
(\mathrm{Na})_{i} /(\mathrm{Na})_{0}=\left[\left(\mathrm{HCO}_{3}\right)_{0} /\left(\mathrm{HCO}_{3}\right)_{i}\right]^{n}\left[(\mathrm{~K})_{0} /(\mathrm{K})_{i}\right]^{n-1} \text {. }
$$

Based on this last equation, the general experimental strategy for calculating $n$ was to set $\left(\mathrm{K}^{+}\right)_{0}=\left(\mathrm{K}^{+}\right)_{i}$ and find the conditions under which an inward $\mathrm{HCO}_{3}^{-}$gradient would just balance an outward $\mathrm{Na}^{+}$gradient so as to bring net flux through the system to zero, or to set $\left(\mathrm{HCO}_{3}^{-}\right)_{0}=\left(\mathrm{HCO}_{3}^{-}\right)_{\mathrm{i}}$ and find the conditions under which an inward $\mathrm{K}^{+}$gradient would just balance an outward $\mathrm{Na}^{+}$gradient so as to bring net flux to zero.

1. Abbreviations used in this paper: TMA, tetramethylammonium.
The results of an experiment utilizing the first approach are illustrated in Fig. 1. Membrane vesicles were preloaded with ${ }^{22} \mathrm{Na}$ and then diluted 10-fold so that a 10:1 outward $\mathrm{Na}^{+}$gradient was imposed. The composition of the diluting media was adjusted to impose different inward $\mathrm{HCO}_{3}^{-}$gradients while maintaining $\left(\mathrm{K}^{+}\right)_{\mathrm{o}}=\left(\mathrm{K}^{+}\right)_{\mathrm{i}}$ in the presence of valinomycin. The net change in intravesicular content of ${ }^{22} \mathrm{Na}$ was then assayed over the 3-s period immediately following the imposition of these ion gradients. Over this time interval, no net flux of ${ }^{22} \mathrm{Na}$ could be detected in the absence of a $\mathrm{CO}_{2} / \mathrm{HCO}_{3}^{-}$buffer system. Thus, under the conditions of this and the following experiments, the measured net fluxes of $\mathrm{Na}^{+}$entirely represent $\mathrm{HCO}_{3}^{-}$-dependent transport (i.e., $\mathrm{Na}^{+}-\mathrm{HCO}_{3}^{-}$cotransport). As shown in Fig. 1, imposing a 3.2:1 inward $\mathrm{HCO}_{3}^{-}$gradient induced the net influx of $\mathrm{Na}^{+}$against its own 10:1 outward gradient. According to Eq. 4 , if $n=2$, the cotransport system would have been at equilibrium and no net flux would have been observed under these conditions. The fact that the 3.2:1 inward $\mathrm{HCO}_{3}^{-}$gradient could overcome the 10:1 outward $\mathrm{Na}^{+}$gradient as a driving force indicates that $n$ must be $>2$. When a 2.2:1 inward $\mathrm{HCO}_{3}^{-}$gradient was imposed, no net $\mathrm{Na}^{+}$flux was observed, consistent with $n=3$. Finally, when an inward $\mathrm{HCO}_{3}^{-}$gradient of only 1.2:1 was imposed, net $\mathrm{Na}^{+}$efflux down its concentration gradient was observed. The value of $n$ would have had to be 12 for this to be the condition for equilibrium. Thus, the results of this experiment indicate that the $\mathrm{HCO}_{3}^{-}: \mathrm{Na}^{+}$stoichiometry must be $>2: 1$ and

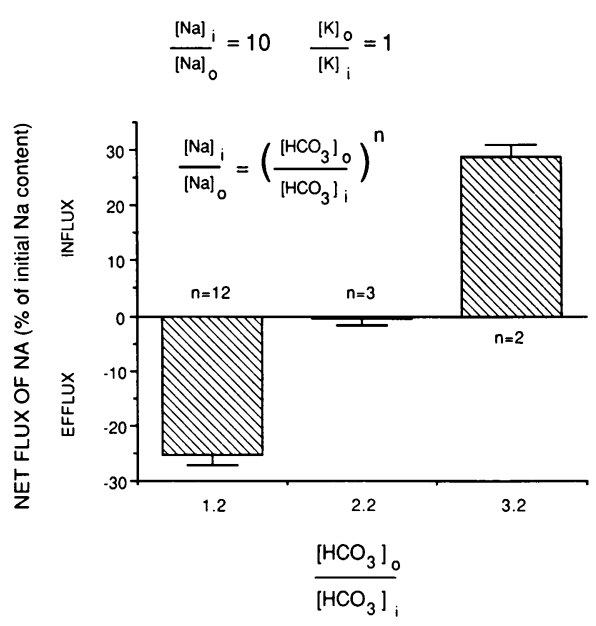

Figure 1. Net $\mathrm{Na}^{+}$flux in the presence of a 10:1 outward $\mathrm{Na}^{+}$gradient and varying inward $\mathrm{HCO}_{3}^{-}$gradients. Basolateral membrane vesicles were preequilibrated for $120 \mathrm{~min}$ at $20^{\circ} \mathrm{C}$ in a medium that consisted of $1 \mathrm{mM}^{22} \mathrm{Na}$-gluconate, $52 \mathrm{mM}$ TMA-gluconate, $42 \mathrm{mM}$ Hepes, 23 mM TMA-OH, gassed with $90 \% \mathrm{~N}_{2}, 10 \% \mathrm{CO}_{2}$, and that contained in addition either $38 \mathrm{mM}$ mannitol, $14 \mathrm{mM}$ Mes, $22 \mathrm{mM} \mathrm{K}-\mathrm{HCO}_{3}$, and $55 \mathrm{mM}$ K-gluconate, pH 7.08; $43 \mathrm{mM}$ mannitol, $9 \mathrm{mM}$ Mes, $32 \mathrm{mM}$ $\mathrm{K}-\mathrm{HCO}_{3}$, and $45 \mathrm{mM} \mathrm{K}$-gluconate, $\mathrm{pH} \mathrm{7.24;} \mathrm{or} 50 \mathrm{mM}$ mannitol, 2 $\mathrm{mM}$ Mes, $59 \mathrm{mM} \mathrm{K}-\mathrm{HCO}_{3}$, and $18 \mathrm{mM} \mathrm{K}$-gluconate, $\mathrm{pH}$ 7.51; corresponding to inward $\mathrm{HCO}_{3}^{-}$gradients of 3.2, 2.2 or $1.2: 1$, respectively. Intravesicular content of ${ }^{22} \mathrm{Na}$ was then measured before and $3 \mathrm{~s}$ after 1:10 dilution and incubation of the vesicles in a medium of final composition $53 \mathrm{mM}$ TMA-gluconate, $42 \mathrm{mM}$ Hepes, $51 \mathrm{mM}$ mannitol, 1 mM Mes, $24 \mathrm{mM}$ TMA-OH, $71 \mathrm{mM} \mathrm{K}-\mathrm{HCO}_{3}$, and $6 \mathrm{mM} \mathrm{K}$-gluconate, pH 7.60, gassed with $90 \% \mathrm{~N}_{2}, 10 \% \mathrm{CO}_{2}$. Values shown for net flux represent means $\pm \mathrm{SE}$ for three separate experiments performed in triplicate on three different membrane preparations. For each imposed $\mathrm{HCO}_{3}^{-}$gradient, the value of $n$ is shown that would satisfy the illustrated form of Eq. 4, which applies when $\left(\mathrm{K}^{+}\right)_{0}=\left(\mathrm{K}^{+}\right)_{\mathrm{i}}$. 
$<12: 1$, with equilibrium observed under conditions corresponding to $n=3$.

The goal of the next experiment (Fig. 2) was to define the stoichiometry of cotransport more precisely. In this case, vesicles were preloaded with ${ }^{22} \mathrm{Na}$ and then different outward $\mathrm{Na}^{+}$gradients were imposed by diluting 1 vol of $\mathrm{Na}^{+}$-loaded vesicles in different volumes of $\mathrm{Na}^{+}$-free media. The composition of the diluting media was adjusted to impose a fixed inward $\mathrm{HCO}_{3}^{-}$ gradient of 3:1 while maintaining $\left(\mathrm{K}^{+}\right)_{0}=\left(\mathrm{K}^{+}\right)_{i}$ in the presence of valinomycin. The net change in intravesicular content of ${ }^{22} \mathrm{Na}$ was then assayed over the 3-s period immediately following the imposition of these ion gradients. As shown in Fig. 2, when a 9:1 outward $\mathrm{Na}^{+}$gradient was imposed, the 3:1 inward $\mathrm{HCO}_{3}^{-}$ gradient induced the net influx of $\mathrm{Na}^{+}$. If $n=2$, the cotransport sytem would have been at equilibrium and no net flux would have been observed under these conditions. The fact that the 3:1 inward $\mathrm{HCO}_{3}^{-}$gradient could overcome the 9:1 outward $\mathrm{Na}^{+}$ gradient as a driving force indicates that $n$ must be $>2$. The 3:1 inward $\mathrm{HCO}_{3}^{-}$gradient even caused net $\mathrm{Na}^{+}$influx when outward $\mathrm{Na}^{+}$gradients of $12.5: 1$ or 17.5:1 were imposed, which would have brought the system to equilibrium if $n$ were equal to 2.3 or 2.6 , respectively. These results indicate that $n$ must be $>2.6$. In contrast, when a 46.7:1 outward $\mathrm{Na}^{+}$gradient was imposed, which would have brought the system to equilibrium if $n=3.5$, net $\mathrm{Na}^{+}$efflux was observed. Thus, this experiment indicates that the value for $n$ must be between 2.6 and 3.5. Indeed, when outward $\mathrm{Na}^{+}$gradients of $24.2: 1$ and 33.5:1 were

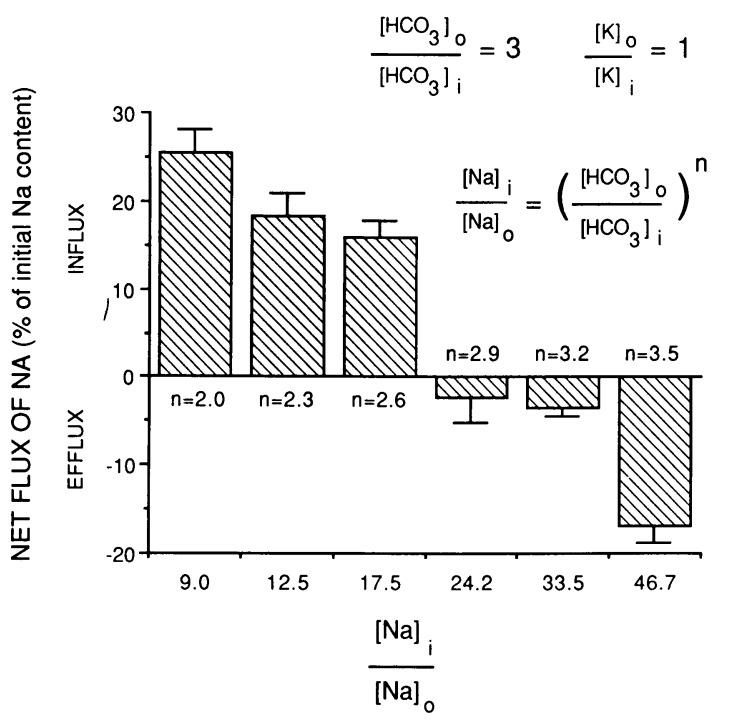

Figure 2. Net $\mathrm{Na}^{+}$flux in the presence of a 3:1 inward $\mathrm{HCO}_{3}^{-}$gradient and varying outward $\mathrm{Na}^{+}$gradients. Basolateral membrane vesicles were preequilibrated for $120 \mathrm{~min}$ at $20^{\circ} \mathrm{C}$ in a medium that consisted of $1 \mathrm{mM}^{22} \mathrm{Na}$-gluconate, $52 \mathrm{mM}$ TMA-gluconate, $42 \mathrm{mM}$ Hepes, 23 mM TMA-OH, $38 \mathrm{mM}$ mannitol, $14 \mathrm{mM}$ Mes, $21 \mathrm{mM} \mathrm{K}-\mathrm{HCO}_{3}$, and $50 \mathrm{mK}$ K-gluconate, $\mathrm{pH} 7.06$, gassed with $90 \% \mathrm{~N}_{2}, 10 \% \mathrm{CO}_{2}$. Intravesicular content of ${ }^{22} \mathrm{Na}$ was then measured before and $3 \mathrm{~s}$ after 1:9, $1: 12.5,1: 17.5,1: 24.2,1: 33.5$, or 1:46.7 dilution and incubation of the vesicles in a medium of final composition $53 \mathrm{mM}$ TMA-gluconate, 42 mM Hepes, $23 \mathrm{mM}$ TMA-OH, $50 \mathrm{mM}$ mannitol, $2 \mathrm{mM}$ Mes, $63 \mathrm{mM}$ $\mathrm{K}-\mathrm{HCO}_{3}$, and $8 \mathrm{mM} \mathrm{K}$-gluconate, $\mathrm{pH} 7.50$, gassed with $90 \% \mathrm{~N}_{2}, 10 \%$ $\mathrm{CO}_{2}$. Values shown for net flux represent means \pm SE for three separate experiments performed in triplicate on three different membrane preparations. For each imposed $\mathrm{Na}^{+}$gradient, the value of $n$ is shown that would satisfy the illustrated form of Eq. 4, which applies when $\left(\mathrm{K}^{+}\right)$。 $=\left(\mathrm{K}^{+}\right)_{\mathrm{i}}$. imposed, corresponding to $n$ values of 2.9 and 3.2 respectively, no significant net $\mathrm{Na}^{+}$flux was observed, again consistent with a cotransport stoichiometry of $3 \mathrm{HCO}_{3}^{-}: \mathrm{Na}^{+}$.

In the experimental approach illustrated in Fig. 3, membrane vesicles were preloaded with ${ }^{22} \mathrm{Na}$ and then diluted 10 -fold so that a 10:1 outward $\mathrm{Na}^{+}$gradient was imposed, and the composition of the diluting media was adjusted to impose different inward $\mathrm{K}^{+}$gradients in the presence of valinomycin while maintaining $\left(\mathrm{HCO}_{3}^{-}\right)_{0}=\left(\mathrm{HCO}_{3}^{-}\right)_{i}$. The net change in intravesicular content of ${ }^{22} \mathrm{Na}$ was then assayed over the 3-s period immediately following the imposition of these ion gradients. Shown at the far right in Fig. 3, imposing a 10:1 inward $\mathrm{K}^{+}$gradient induced the net influx of $\mathrm{Na}^{+}$against its own 10:1 outward gradient. According to Eq. 4, if $n=2$, the cotransport system would have been at equilibrium and no net flux would have been observed under these conditions. The fact that the 10:1 inward $\mathrm{K}^{+}$gradient could overcome the $10: 1$ outward $\mathrm{Na}^{+}$gradient as a driving force indicates that $n$ must be $>2$. When a 4.2:1 inward $\mathrm{K}^{+}$gradient was imposed, net $\mathrm{Na}^{+}$influx was again observed, indicating that $n$ must be $>2.6$. In contrast, when a 2.2:1 inward $\mathrm{K}^{+}$gradient was imposed, which would have brought the system to equilibrium if $n=4.0$, net $\mathrm{Na}^{+}$efflux was observed. Thus, this experiment indicates that the value for $n$ must be between 2.6 and 4.0. Indeed, when a 3.2:1 inward $\mathrm{K}^{+}$gradient was imposed no

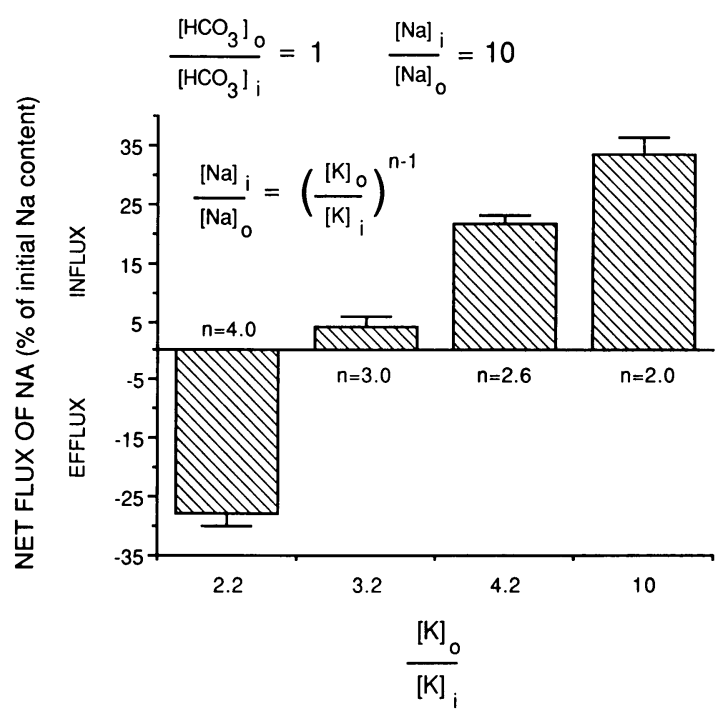

Figure 3. Net $\mathrm{Na}^{+}$flux in the presence of a $10: 1$ outward $\mathrm{Na}^{+}$gradient and varying inward $\mathrm{K}^{+}$gradients. Basolateral membrane vesicles were preequilibrated for $120 \mathrm{~min}$ at $20^{\circ} \mathrm{C}$ in a medium that consisted of 1 $\mathrm{mM}^{22} \mathrm{Na}$-gluconate, $66 \mathrm{mM}$ TMA-gluconate, $52 \mathrm{mM}$ mannitol, 42 mM Hepes, 21 mM TMA-OH, pH 7.50, gassed with $90 \% \mathrm{~N}_{2}, 10 \%$ $\mathrm{CO}_{2}$, and that contained in addition either $46 \mathrm{mM}$ choline- $\mathrm{HCO}_{3}$ and $11 \mathrm{mM} \mathrm{K}-\mathrm{HCO}_{3}, 30 \mathrm{mM}$ choline- $\mathrm{HCO}_{3}$ and $27 \mathrm{mM} \mathrm{K}-\mathrm{HCO}_{3}, 22$ $\mathrm{mM}$ choline- $\mathrm{HCO}_{3}$ and $35 \mathrm{mM} \mathrm{K}-\mathrm{HCO}_{3}$, or $5 \mathrm{mM}$ choline- $\mathrm{HCO}_{3}$ and $52 \mathrm{mM} \mathrm{K}-\mathrm{HCO}_{3}$, corresponding to inward $\mathrm{K}^{+}$gradients of 10 , $4.2,3.2$, or $2.2: 1$, respectively. Intravesicular content of ${ }^{22} \mathrm{Na}$ was then measured before and $3 \mathrm{~s}$ after 1:10 dilution and incubation of the vesicles in a medium of final composition $7 \mathrm{mM}$ TMA-gluconate, $42 \mathrm{mM}$ Hepes, $21 \mathrm{mM}$ TMA-OH, $5 \mathrm{mM}$ choline- $\mathrm{HCO}_{3}, 52 \mathrm{mM} \mathrm{K}-\mathrm{HCO}_{3}$, and $60 \mathrm{mM}$ K-gluconate, $\mathrm{pH} 7.50$, gassed with $90 \% \mathrm{~N}_{2}, 10 \% \mathrm{CO}_{2}$. Values shown for net flux represent means \pm SE for three separate experiments performed in triplicate on three different membrane preparations. For each imposed $\mathrm{K}^{+}$gradient, the value of $n$ is shown that would satisfy the illustrated form of Eq. 4, which applies when $\left(\mathrm{HCO}_{3}^{-}\right)_{\mathrm{o}}=\left(\mathrm{HCO}_{3}^{-}\right)_{\mathrm{i}}$. 
significant net $\mathrm{Na}^{+}$flux was observed, consistent with a cotransport stoichiometry of $3 \mathrm{HCO}_{3}^{-}: \mathrm{Na}^{+}$.

A similar approach was used in the next experiment (Fig. 4) to define the stoichiometry of cotransport more precisely. In this case, vesicles were preloaded with ${ }^{22} \mathrm{Na}$, and then different outward $\mathrm{Na}^{+}$gradients were imposed by diluting 1 vol of $\mathrm{Na}^{+}$loaded vesicles in different volumes of $\mathrm{Na}^{+}$-free media. The composition of the diluting media was adjusted to impose a fixed inward $\mathrm{K}^{+}$gradient of 3:1 in the presence of valinomycin while maintaining $\left(\mathrm{HCO}_{3}^{-}\right)_{0}=\left(\mathrm{HCO}_{3}^{-}\right)_{\mathrm{i}}$. The net change in intravesicular content of ${ }^{22} \mathrm{Na}$ was then assayed over the 3-s period immediately following the imposition of these ion gradients. As shown in Fig. 4, the 3:1 inward $\mathrm{K}^{+}$gradient induced the net influx of $\mathrm{Na}^{+}$in the presence of outward $\mathrm{Na}^{+}$gradients of $3: 1$, 4.2:1 or 5.8:1, which would have brought the system to equilibrium if $n=2.0,2.3$, or 2.6, respectively. This clearly indicates that $n$ must be $>2.6$. In contrast, when a 15.5:1 outward $\mathrm{Na}^{+}$ gradient was imposed, which would have brought the system to

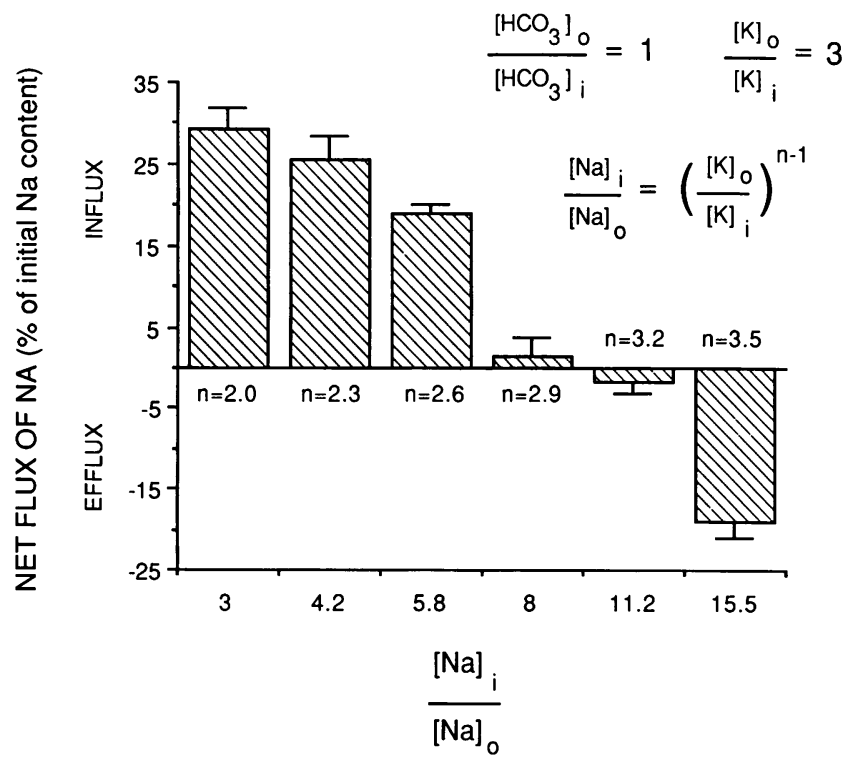

Figure 4. Net $\mathrm{Na}^{+}$flux in the presence of $3: 1$ inward $\mathrm{K}^{+}$gradient and varying outward $\mathrm{Na}^{+}$gradients. Basolateral membrane vesicles were preequilibrated for $120 \mathrm{~min}$ at $20^{\circ} \mathrm{C}$ in a medium that consisted of 1 $\mathrm{mM}^{22} \mathrm{Na}$-gluconate, $66 \mathrm{mM}$ TMA-gluconate, $52 \mathrm{mM}$ mannitol, 42 $\mathrm{mM}$ Hepes, $21 \mathrm{mM}$ TMA-OH, $27 \mathrm{mM}$ choline- $\mathrm{HCO}_{3}$, and $30 \mathrm{mM}$ $\mathrm{K}-\mathrm{HCO}_{3}, \mathrm{pH} 7.50$, gassed with $90 \% \mathrm{~N}_{2}, 10 \% \mathrm{CO}_{2}$. Intravesicular content of ${ }^{22} \mathrm{Na}$ was then measured before and $3 \mathrm{~s}$ after 1:3, 1:4.2, 1:5.8, $1: 8,1: 11.2$, or $1: 15.5$ dilution and incubation of the vesicles in a medium of final composition $53 \mathrm{mM}$ TMA-gluconate, $42 \mathrm{mM}$ Hepes, 2 mM TMA-OH, pH 7.50, gassed with $90 \% \mathrm{~N}_{2}, 10 \mathrm{CO}_{2}$, and that contained in addition either $24 \mathrm{mM}$ TMA-gluconate, $43 \mathrm{mM} \mathrm{K}$-gluconate, $47 \mathrm{mM} \mathrm{K}-\mathrm{HCO}_{3}$, and $10 \mathrm{mM}$ choline- $\mathrm{HCO}_{3} ; 28 \mathrm{mM}$ TMAgluconate, $39 \mathrm{mM} \mathrm{K}$-gluconate, $51 \mathrm{mM} \mathrm{K}-\mathrm{HCO}_{3}$, and $6 \mathrm{mM}$ choline- $\mathrm{HCO}_{3} ; 23 \mathrm{mM}$ TMA-gluconate, $44 \mathrm{mM} \mathrm{K}$-gluconate, $46 \mathrm{mM}$ $\mathrm{K}-\mathrm{HCO}_{3}$, and $11 \mathrm{mM}$ choline- $\mathrm{HCO}_{3} ; 21 \mathrm{mM}$ TMA-gluconate, 46 $\mathrm{mM} \mathrm{K}$-gluconate, $44 \mathrm{mM} \mathrm{K}-\mathrm{HCO}_{3}$, and $13 \mathrm{mM}$ choline- $\mathrm{HCO}_{3} ; 19$ mM TMA-gluconate, $48 \mathrm{mM} \mathrm{K}$-gluconate, $42 \mathrm{mM} \mathrm{K}-\mathrm{HCO}_{3}$, and 15 $\mathrm{mM}$ choline- $\mathrm{HCO}_{3}$; or $18 \mathrm{mM}$ TMA-gluconate, $49 \mathrm{mM} \mathrm{K}$-gluconate, $41 \mathrm{mM} \mathrm{K}-\mathrm{HCO}_{3}$, and $16 \mathrm{mM}$ choline- $\mathrm{HCO}_{3}$; respectively. Values shown for net flux represent means $\pm \mathrm{SE}$ for three separate experiments performed in triplicate on three different membrane preparations. For each imposed $\mathrm{Na}^{+}$gradient, the value of $n$ is shown that would satisfy the illustrated form of Eq. 4, which applies when $\left(\mathrm{HCO}_{3}^{-}\right)_{0}=\left(\mathrm{HCO}_{3}^{-}\right)_{i}$. equilibrium if $n=3.5$, net $\mathrm{Na}^{+}$efflux was observed. Thus, this experiment indicates that the value for $n$ must be between 2.6 and 3.5. Indeed, when outward $\mathrm{Na}^{+}$gradients of $8: 1$ and 11.2:1 were imposed, corresponding to $n$ values of 2.9 and 3.2 respectively, no significant net $\mathrm{Na}^{+}$flux was observed, again consistent with a cotransport stoichiometry of $3 \mathrm{HCO}_{3}^{-}: \mathrm{Na}^{+}$.

It should be emphasized that although all of the above results are consistent with a cotransport stoichiometry of $3 \mathrm{HCO}_{3}^{-}$per $\mathrm{Na}^{+}$, they are equally consistent with any transport process in which there is the net transfer of three equivalents of base, one $\mathrm{Na}^{+}$, and two negative charges per transport event. In our experimental protocols using a $\mathrm{CO}_{2} / \mathrm{HCO}_{3}^{-}$buffer system, whenever inward $\mathrm{HCO}_{3}^{-}$gradients were imposed, inward $\mathrm{OH}^{-}$and outward $\mathrm{H}^{+}$gradients of equal magnitude were also imposed. Thus, for example, the cotransport of $\mathrm{Na}^{+}$with $3 \mathrm{HCO}_{3}^{-}$, the cotransport of $\mathrm{Na}^{+}$with $2 \mathrm{HCO}_{3}^{-}$and $1 \mathrm{OH}^{-}$, and the cotransport of $\mathrm{Na}^{+}$with $2 \mathrm{HCO}_{3}^{-}$in exchange for $1 \mathrm{H}^{+}$are thermodynamically equivalent processes that cannot be distinguished by the approach we have utilized. Similarly, our approach will not discriminate between the cotransport $\mathrm{Na}^{+}$with $3 \mathrm{HCO}_{3}^{-}$and the cotransport of $\mathrm{Na}^{+}$with $1 \mathrm{HCO}_{3}^{-}$and $1 \mathrm{CO}_{3}^{-2}$.

In conclusion, we have demonstrated that the stoichiometry of the $\mathrm{Na}^{+}-\mathrm{HCO}_{3}^{-}$cotransport system in rabbit renal basolateral membrane vesicles is $3 \mathrm{HCO}_{3}^{-}: \mathrm{Na}^{+}$or a thermodynamically equivalent process. With such a stoichiometry, the inside-negative membrane potential is sufficient to drive $\mathrm{HCO}_{3}^{-}$exit against the inward concentration gradients of $\mathrm{HCO}_{3}^{-}$and $\mathrm{Na}^{+}$that are present across the basolateral membrane of the intact proximal tubule cell under physiologic conditions $(5,13)$.

\section{Acknowledgments}

The excellent technical assistance of Thecla Massad and Jane Ach is gratefully acknowledged.

This work was supported by National Institutes of Health Grants AM-33793 and AM-17433, and an Established Investigator Award to Dr. Aronson from the American Heart Association.

\section{References}

1. Aronson, P. S. 1983. Mechanisms of active $\mathrm{H}^{+}$secretion in the proximal tubule. Am. J. Physiol. 245:F647-F659.

2. Boron, W. F., and E. L. Boulpaep. 1983. Intracellular pH regulation in the renal proximal tubule of the salamander. Basolateral $\mathrm{HCO}_{3}^{-}$transport. J. Gen. Physiol. 81:53-94.

3. Biagi, B. A. 1985. Effects of the anion transport inhibitor, SITS, on the proximal straight tubule of the rabbit perfused in vitro. J. Membr. Biol. 88:25-31.

4. Alpern, R. J. 1985. Mechanism of basolateral membrane $\mathrm{H}^{+} / \mathrm{OH}^{-} / \mathrm{HCO}_{3}^{-}$transport in the rat proximal convoluted tubule. A sodium-coupled electrogenic process. J. Gen. Physiol. 86:613-636.

5. Yoshitomi, K., B.-C. Burckhardt, and E. Frömter. 1985. Rheogenic sodium-bicarbonate cotransport in the peritubular cell membrane of rat renal proximal tubule. Pfluegers Arch. Eur. J. Physiol. 405:360-366.

6. Sasaki, S., T. Shiigai, and J. Takeuchi. 1985. Intracellular pH in the isolated perfused rabbit proximal straight tubule. Am. J. Physiol. 249:F417-F423.

7. Jentsch, T. J., B. S. Schill, P. Schwartz, H. Matthes, S. K. Keller, and M. Wiederholt. 1985. Kidney epithelial cells of monkey origin (BSC1) express a sodium bicarbonate cotransport. J. Biol. Chem. 260:1555415560. 
8. Biagi, B. A., and M. Sohtell. 1986. Electrophysiology of basolateral transport in the rabbit proximal tubule. Am J. Physiol. 250:F267-F272.

9. Alpern, R. J., and M. Chambers. 1986. Cell pH in the rat proximal convoluted tubule. Regulation by luminal and peritubular $\mathrm{pH}$ and sodium concentration. J. Clin. Invest. 78:502-510.

10. Jentsch, T. J., P. Schwartz, B. S. Schill, B. Langner, A. P. Lepple, S. K. Keller, and M. Wiederholt. 1986. Kinetic properties of the sodium bicarbonate (carbonate) symport in monkey kidney epithelial cells (BSC1). J. Biol. Chem. 261:10673-10679.

11. Jentsch, T. J., S. K. Keller, M. Koch, and M. Wiederholt. 1984. Evidence for coupled transport of bicarbonate and sodium in cultured bovine corneal endothelial cells. J. Membr. Biol. 81:189-204.

12. Jentsch, T. J., T. R. Stahlknecht, H. Hollwede, D. G. Fischer, S. K. Keller, and M. Wiederholt. 1985. A bicarbonate-dependent process inhibitable by disulfonic stilbenes and a Na${ }^{+} / \mathrm{H}^{+}$exchange mediate ${ }^{22} \mathrm{Na}^{+}$ uptake into cultured bovine corneal endothelium. J. Biol. Chem. 260: 795-801.

13. Yoshitomi, K., and E. Frömter. 1985. How big is the electrochemical potential difference of $\mathrm{Na}^{+}$across rat renal proximal tubular cell membranes in vivo? Pfluegers Arch. Eur. J. Physiol. 405(Suppl. 1): S121-S126.

14. Eaton, D. C., K. L. Hamilton, and K. E. Johnson. 1984. Intracellular acidosis blocks the basolateral $\mathrm{Na}-\mathrm{K}$ pump in rabbit urinary bladder. Am. J. Physiol. 247:F946-F954.

15. Yoshitomi, K., and E. Frömter. 1984. Cell pH of rat renal proximal tubule in vivo and the conductive nature of peritubular $\mathrm{HCO}_{3}^{-}$ $\left(\mathrm{OH}^{-}\right)$exit. Pfluegers Arch. Eur. J. Physiol. 402:300-305.

16. Grassl, S. M., and P. S. Aronson. 1986. $\mathrm{Na}^{+} / \mathrm{HCO}_{3}^{-}$cotransport in basolateral membrane vesicles isolated from rabbit renal cortex. $J$. Biol. Chem. 261:8778-8783.

17. Aronson, P. S. 1981. Identifying secondary active solute transport in epithelia. Am. J. Physiol. 240:F1-F11.

18. Kinsella, J. L., and P. S. Aronson. 1982. Determination of the coupling ratio for $\mathrm{Na}^{+}-\mathrm{H}^{+}$exchange in renal microvillus membrane vesicles. Biochim. Biophys. Acta. 689:161-164.

19. Turner, R. J., and A. Moran. 1982. Stoichiometric studies of the renal outer cortical brush border membrane D-glucose transporter. $J$. Membr. Biol. 67:73-80. 